\title{
THREE NEW RECORDS OF FISHES AND THEIR PARASITE FAUNA FROM POMERANIAN BAY, BALTIC SEA
}

\author{
Beata WIĘCASZEK ${ }^{1}$, Ewa SOBECKA ${ }^{1}$, Sławomir KESZKA ${ }^{2}$, Remigiusz PANICZ ${ }^{3}$, \\ Klaudia GÓRECKA ${ }^{1}$, Angelika LINOWSKA ${ }^{1}$, and Sebastian KRÓL ${ }^{4}$ \\ ${ }^{1}$ Division of Hydrobiology, Ichthyology, and Biotechnology of Breeding, ${ }^{2}$ Division of Aquaculture, ${ }^{3}$ Division of \\ Meat Technology ${ }^{4}$ Division of Fisheries Management and Water Protection, Faculty of Food Sciences and Fisheries, \\ West Pomeranian University of Technology in Szczecin, Poland
}

Więcaszek B., Sobecka E., Keszka S., Panicz R., Górecka K., Linowska A., Król S. 2019. Three new records of fishes and their parasite fauna from Pomeranian Bay, Baltic Sea. Acta Ichthyol. Piscat. 49 (1): 65-73.

\begin{abstract}
This paper reports the occurrence of three new fish species, extremely rare in the Baltic Sea, and provides new data on their parasite fauna. The fish collected were Barbus barbus (Linnaeus, 1758), Salvelinus fontinalis (Mitchill, 1814), and Scophthalmus rhombus (Linnaeus, 1758). Their taxonomic identity was confirmed through genetic analyses using DNA extracted from fin clips. The stomach contents were examined, and age was determined by otolith or scale readings. Parasitological examinations focused on the skin, vitreous humour, eye lenses, mouth and nasal cavities, gills, gonads, viscera, and muscles. Furthermore, the changes of fish species composition over 20 years in Pomeranian Bay were analysed. The sequence comparisons against GenBank records revealed that sequences obtained for B. barbus and $S$. rhombus from Pomeranian Bay represent new rhodopsin barcodes. Record of the juvenile B. barbus in this study is the first in the Baltic Sea. Scophthalmus rhombus is a new host for the ciliate Trichodina jadranica, while Neogobius melanostomus (Pallas, 1814) is a new food item in the diet of $S$. rhombus in the Baltic Sea. Acanthocephalan Pomphorhynchus laevis found in the adult specimen of B. barbus and myxozoan Myxobolus musculi, noted in the juvenile specimen, have not been recorded previously in this fish species in Polish waters. Species collected as bycatch can potentially be used for monitoring potential changes in the overall fish community structure and biodiversity.
\end{abstract}

Keywords: Neogobius melanostomus, Salvelinus fontinalis, Barbus barbus, Scophthalmus rhombus, ichthyofauna, Pomeranian Bay, parasite fauna

\section{INTRODUCTION}

Since the mid-1990s, the Baltic Marine Biologists (BMB) has encouraged research on non-commercial coastal fishes with regard to the occurrence, distribution, and the overall ecological status (Winkler et al. 2000, Więcaszek et al. 2015).

Pomeranian Bay (Bornholm Basin; ICES division IIId, subdivision SD 24), a highly dynamic environment, is a large, shallow basin off the Polish and German coasts, with the depth not exceeding $30 \mathrm{~m}$. The salinity at the bottom layers ranges from $7.2 \%{ }^{* *}$ to $7.6 \%$ (mean $7.4 \%$ ), while at the surface layers it is $3.9 \% 0-7.3 \%$ (mean $6.2 \%$ ). The water temperature at the bottom layers ranges from 7.0 to $22.3^{\circ} \mathrm{C}$ (mean $16.0^{\circ} \mathrm{C}$ ), while at the surface layers it is $7.8^{-}$ $23.4^{\circ} \mathrm{C}$ (mean $16.4^{\circ} \mathrm{C}$ ) (Abbas et al. 2015). Pomeranian Bay is a water-mixing region with two important factors: riverine water input and water exchange with adjacent open seawaters that influence the hydrological conditions of the area (Beszczyńska-Möller 1999). Data on the fish species composition of Pomeranian Bay quite recent, but the monitoring surveys in 2007-2008 and 2011-2015 conducted by Dudko et al. (2015) focused on commercial species, mainly Clupea harengus Linnaeus, 1758, Sprattus sprattus (Linnaeus, 1758), Gadus morhua Linnaeus, 1758, Platichthys flesus (Linnaeus, 1758), Sander lucioperca (Linnaeus, 1758), and Perca fluviatilis Linnaeus, 1758. However, since surveys usually collect many other species as bycatch, they can potentially be used to monitor changes in the overall fish community structure and biodiversity (Ojaveer et al. 2010). Generally, the information concerning fish species that are caught sporadically or are commercially insignificant is not available (Psuty-Lipska

\footnotetext{
Correspondence: Prof. Beata Więcaszek, Katedra Hydrobiologii, Ichtiologii i Biotechnologii Rozrodu, Wydział Nauk o Żywności i Rybactwa, Zachodniopomorski Uniwersytet Technologiczny, 71-550 Szczecin, ul. Kazimierza Królewicza 4, Poland, phone: +48 91449 6637, e-mail: (BW) beata.wiecaszek@zut.edu.pl, (ES) ewa.sobecka@zut.edu.pl, (SK) slawomir.keszka@zut.edu.pl, (RP) remigiusz.panicz@zut.edu.pl, (KG) klaudia.gorecka@zut.edu.pl, (AL) angelika.linowska@zut.edu.pl, (SK)sebastian.krol@zut.edu.pl.

"In the wake of the growing criticism of the Practical Salinity Scale concept (and especially "PSU" as a "unit"), Acta Ichthyologica et Piscatoria is in favour of expressing salinity in parts per thousand (\%o), regardless if a direct or indirect method was employed to determine the water salinity.
} 
and Garbacik-Wesołowska 1998). In recent years, only Keszka and Raczyński (2002), Czerniejewski et al. 2008, Więcaszek et al. (2011, 2015), and Panicz and Keszka (2016) have presented results of studies on endangered, non-commercial, new, or visiting fish species recorded as bycatch during monitoring surveys in Pomeranian Bay. Next to nothing is known about the relations between the age and length, the diet, and the parasite fauna of the bycatch fishes from Pomeranian Bay.

The main objectives of the presently reported study were to

- Report on the occurrence of three new fish species captured as bycatch during monitoring surveys in 2014 and 2015.

- Provide the relevant biological data, especially concerning their parasite fauna.

- Present a checklist of the fish species recorded in Pomeranian Bay, thus contributing to the knowledge on the Pomeranian Bay biodiversity.

\section{MATERIALS AND METHODS}

The study material was collected in May 2014 and in May 2015 as bycatch during monitoring surveys focusing on commercial fish species. The survey was carried out in Pomeranian Bay from the research vessel $S N B-A R-1$ (depicted on the back inner cover of this journal) with trawls (mesh size of 10-20 mm), at the depth of 9.8-14.6 $\mathrm{m}$, over the sandy bottom (Table 1).

The fish collected were one juvenile and one adult specimen each of common barbel, Barbus barbus (Linnaeus, 1758) (Cyprinidae), one specimen of brook trout, Salvelinus fontinalis (Mitchill, 1814) (Salmonidae), and two specimens of brill, Scophthalmus rhombus (Linnaeus, 1758) (Scophthalmidae). All fish specimens collected were measured and weighed. The basic metric measurements and meristic counts of taxonomical significance were taken of each fish specimen and were used to identify the specimens to the species level according to taxonomical keys(Nielsen 1986, KottelatandFreyhof2007). The taxonomic identity of the specimens collected was confirmed through genetic analyses using DNA extracted from fin clips collected from frozen specimens. DNA was isolated using DNeasy Blood and Tissue Kit (Qiagen) following the manufacturer's instructions. The qualitative and quantitative assessments of the extracted DNA were conducted by measuring absorbance with a NanoDrop
2000 UV-VIS spectrophotometer (ThermoScientific). The DNA isolates were separated electrophoretically on $1.5 \%$ agarose gel. Subsequently, partial sequences of the rhodopsin gene (RH1) were amplified using Rod-F2W and Rod-R4n primers described in the paper by Sevilla et al. (2007). All PCRs were performed with REDTaq ReadyMix PCR Reaction Mix (Sigma-Aldrich) on a GeneAmp PCR System 9700 (Applied Biosystems), and PCR products separated on $1.5 \%$ agarose gel. Sequencing of the RH1 PCR products obtained was ordered from Genomed (Warsaw, Poland). Processing the raw sequence reads and further alignments against GenBank nucleotide records was performed using BioEdit and BLAST software, respectively (Altschul et al. 1990, Hall 1999).

The stomach contents were examined following commonly accepted methods, and age was determined by otolith or scale readings. Parasitological examinations focused on the skin, vitreous humour of the eye, eye lenses, mouth and nasal cavities, gills, gonads, gastrointestinal tract, kidneys, swim bladder, urinary bladder, gall bladder, peritoneum, and muscles. The parasites found were prepared for species determination by examining specimens in fresh mounts or after immersion in glycerin under transient light.

\section{RESULTS}

The meristic and metric characters of the taxonomic significance of the specimens examined are presented in Table 2.

The smaller specimen of Barbus barbus was a juvenile (aged $0+$ ) measuring $7.23 \mathrm{~cm}$ SL (the caudal fin was destroyed), while the second specimen was a female (aged $4+$ ) measuring $23.3 \mathrm{~cm}$ SL and $29.0 \mathrm{~cm}$ TL. Figure 1 shows the characteristic structure of the last dorsal fin (spinous, serrated along the entire posterior edge), which distinguished this common barbel from other Barbus species in Europe.

Only undetermined ingested remains were found in the barbel stomachs. Parasitological studies of the muscles of the juvenile specimen indicated the presence of spores of the myxozoan, Myxobolus musculi. In the anterior intestine of the adult barbel 17 specimens of Pomphorhynchus laevis were found. Additionally, there were four specimens of the nematode Rhabdochona hellichi in the mucus from the middle part of the intestine (Table 2).

The collected specimen of Salvelinus fontinalis was a female (4+) measuring $34.6 \mathrm{~cm} \mathrm{SL}$ and $38.0 \mathrm{~cm}$ TL. The

Table 1

Characteristics of fish specimens collected as bycatch in 2014 and 2015 from Pomeranian Bay

\begin{tabular}{lcccccrc}
\hline \multicolumn{1}{c}{ Species } & CS & Depth [m] & Date & SL [cm] & TL [cm] & Weight [g] & Age \\
\hline Barbus barbus & A & $9.8-11.9$ & 6 May 2014 & 7.23 & & 7.31 & $0+\mathrm{S}$ \\
Barbus barbus & B & $9.8-14.6$ & 18 May 2015 & 23.3 & 29.0 & 183.5 & $4+\mathrm{S}$ \\
Salvelinus fontinalis & B & $9.8-14.6$ & 18 May 2015 & 34.6 & 38.0 & 855.0 & $4+\mathrm{O}$ \\
Scophthalmus rhombus & A & $9.8-11.9$ & 6 May 2014 & & 17.0 & 69.6 & $4+\mathrm{O}$ \\
Scophthalmus rhombus & A & $9.8-11.9$ & 6 May 2014 & & 21.5 & 90.6 & $5+\mathrm{O}$ \\
\hline
\end{tabular}

$\mathrm{CS}=$ collection site, $\mathrm{SL}=$ standard length, $\mathrm{TL}=$ total length, $\mathrm{A}=54^{\circ} 00^{\prime}-54^{\circ} 01^{\prime} \mathrm{N}, 014^{\circ} 30^{\prime}-014^{\circ} 35^{\prime} \mathrm{E}, \mathrm{B}=54^{\circ} 00^{\prime}-54^{\circ} 08^{\prime} \mathrm{N}, 014^{\circ} 20^{\prime}-$ $14^{\circ} 35^{\prime} \mathrm{E}, \mathrm{S}=$ scale reading, $\mathrm{O}=$ otolith reading. 
sagitta with annual rings (with lapilla and astriscus) from the specimen are presented in Fig. 2. The stomach was empty and no parasites were found.

The two specimens of Scophthalmus rhombus were males aged 4+ and 5+ that measured 17.0 and $21.5 \mathrm{~cm}$

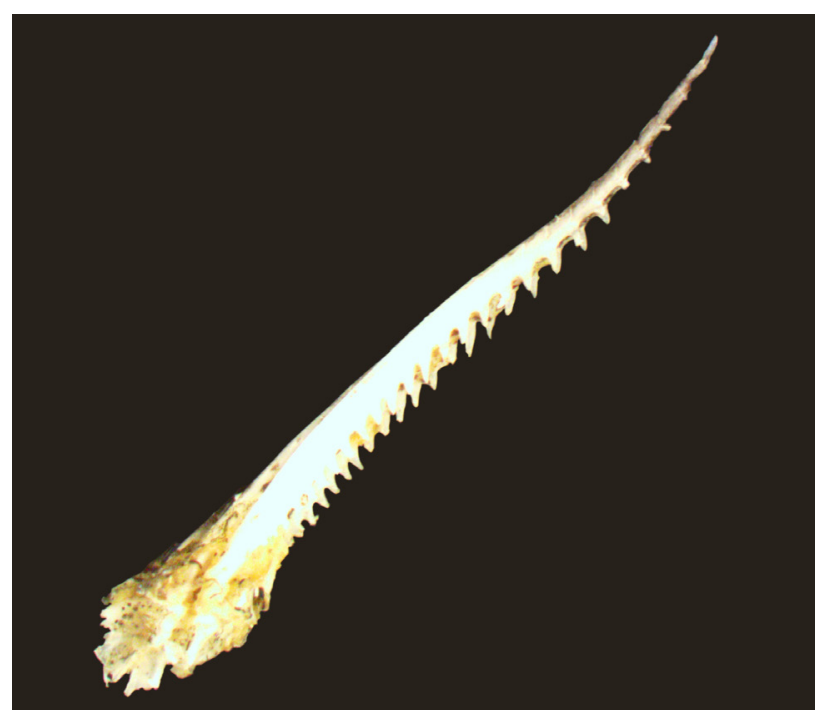

Fig. 1. Structure of the last dorsal fin ray (spinous, serrated along the entire posterior edge) of Barbus barbus, collected as bycatch in 2014 from Pomeranian Bay
$\mathrm{TL}$, respectively. The sagitta with annual rings from the smaller specimen is presented in Fig. 3. Two invasive round gobies, Neogobius melanostomus (Pallas, 1814), $(3.0 \mathrm{~cm}$ SL each) were noted in the stomach of this specimen. A single specimen of the ciliate Trichodina

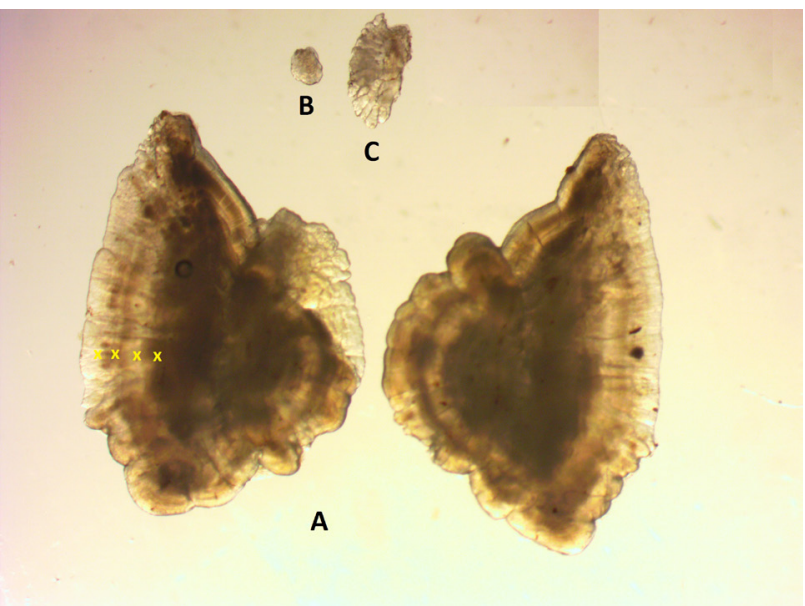

Fig. 2. Sagitta (A) with annual rings, lapillus (B) and asteriscus (C) of the specimen of Salvelinus fontinalis, collected as bycatch in 2015 from Pomeranian Bay

Table 2

Meristic and metric characters of taxonomical significance of Barbus barbus, Salvelinus fontinalis, and Scophthalmus rhombus specimens, collected as bycatch in 2014 and 2015 from Pomeranian Bay

\begin{tabular}{|c|c|c|c|c|}
\hline Character & Barbus barbus & Barbus barbus & Salvelinus fontinalis & $\begin{array}{c}\text { Scophthalmus } \\
\text { rhombus }\end{array}$ \\
\hline & 6 May 2014 & 18 May 2015 & 18 May 2015 & 6 May 2014 \\
\hline \multicolumn{5}{|c|}{ Meristic characters } \\
\hline Dorsal rays & $\mathrm{IV}, 8$ & III, 9 & $3 / 10$ & 78 \\
\hline Anal rays & III, 5 & III, 6 & $3 / 10$ & 57 \\
\hline Pectoral rays & $\mathrm{I}, 17$ & $\mathrm{I}, 17$ & $1 / 12$ & 12 \\
\hline Ventral rays & II, 8 & II, 8 & $1 / 7$ & 6 \\
\hline Caudal rays & - & - & - & 16 \\
\hline LL & 56 & 56 & - & - \\
\hline Gill rakers & - & - & 18 & - \\
\hline Pharyngeal teeth & 5.3.1-1.3.5 & 5.3.1-1.3.5 & - & - \\
\hline \multicolumn{5}{|c|}{ Metric characters expressed as \% of SL } \\
\hline$\overline{\mathrm{TL}}$ & - & - & - & 123.19 \\
\hline $\mathrm{HL}$ & 29.74 & 24.02 & 28.36 & 32.61 \\
\hline Maximum body depth & 21.16 & 21.50 & 26.92 & - \\
\hline Minimum body depth & 10.10 & 9.86 & 11.00 & - \\
\hline Head height & - & - & 19.90 & - \\
\hline Body width & 13.86 & 12.70 & - & - \\
\hline \multicolumn{5}{|c|}{ Metric characters expressed as $\%$ of HL } \\
\hline Length of lower jaw & 29.77 & 29.80 & 74.99 & 16.67 \\
\hline Length of upper jaw & - & - & 69.48 & - \\
\hline Eye diameter & 17.67 & 15.30 & 15.61 & - \\
\hline Interocular distance & 25.58 & 30.27 & - & - \\
\hline Head height & 56.74 & 60.91 & 67.35 & 27.54 \\
\hline Head width & 43.26 & 49.26 & - & - \\
\hline
\end{tabular}

$\mathrm{LL}=$ number of lateral line scales, $\mathrm{TL}=$ total length, $\mathrm{HL}=$ head length, $\mathrm{SL}=$ standard length. 
jadranica, was found on the gills of the smaller fish (Table 2). The morphometric characteristics of the unfixed parasite showed that the adhesive disc diameter was of $35 \mu \mathrm{m}$, and had 24 denticles. The stomach of the larger specimen was empty, and no parasites were found.

Genetic analyses confirmed the taxonomic identity of the common barbel, brook trout, and brill specimens collected in Pomeranian Bay. Sequence alignments revealed that the RH1 sequences of B. barbus and S. rhombus did not match records in the GenBank sequence database; therefore, they were submitted under accession numbers KX980421 and KX980422, respectively. BLAST search revealed that RH1 sequence of $B$. barbus and S. rhombus differed by $5 \mathrm{bp}$ and $1 \mathrm{bp}$ from the most similar sequences (99\%) found in the GenBank submitted under FJ197049.1 and EU638005.1 accession numbers, respectively. Both sequences obtained in this study are the first error-free records of RH1 gene available in GenBank for these species.

\section{DISCUSSION}

Three species described in this paper, Barbus barbus, Salvelinus fontinalis, and Scophthalmus rhombus, were noted for the first time in Pomeranian Bay. Values of the morphological characters of the specimens were consistent with the ranges provided by Nielsen (1986) and Kottelat and Freyhof (2007).

We prepared a checklist with 56 fish and two lamprey species reported from Pomeranian Bay, and among these 58 species, 35 species are marine, 13 are freshwater, and 10 are diadromous. Dudko et al. (2015) reported the occurrence of 41 fish and one lamprey species in Pomeranian Bay, with Sprattus sprattus, Osmerus eperlanus (Linnaeus, 1758), and Platichthys flesus dominating the catches (jointly 66\% in terms of numbers). Psuty-Lipska and Garbacik-Wesołowska (1998) and Dudko et al. (2015) reported different fish species

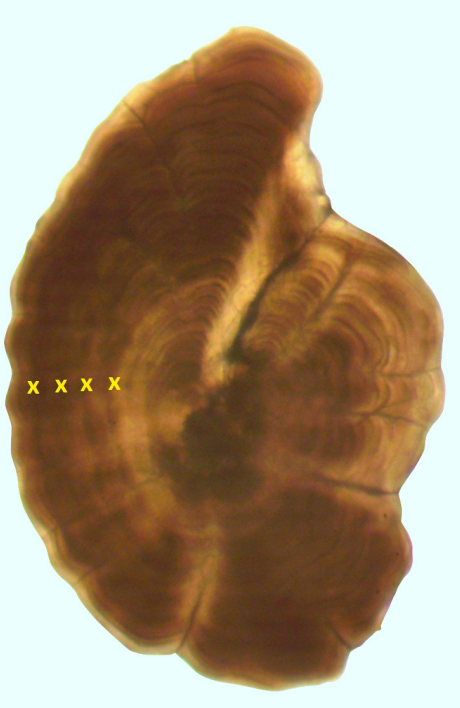

Fig. 3. Sagitta with annual rings of the smaller specimen of Scophthalmus rhombus, collected as bycatch in 2014 from Pomeranian Bay composition in Pomeranian Bay, which probably depended on the season and the distance from land. The checklist of fish and lamprey species in Pomeranian Bay, is presented in Table 3. Dudko et al. (2015) listed two species of the Gobiidae as permanent residents of Pomeranian Bay: Pomatoschistus minutus (Pallas, 1770) and Neogobius melanostomus. The abundance of the latter species has increased markedly since 2007-2008. First catches of this species were recorded in the area in 2003 (Winkler 2006), confirmed by our own study in 2006 (authors' unpublished data). In this study Neogobius melanostomus was found as a new food item in the diet of Scophthalmus rhombus, thus becoming a new and important link in the trophic structure of Pomeranian Bay. It was previously reported as a new prey for predatory fish like Gadus morhua, Perca fluviatilis, Sander lucioperca in Pomeranian Bay (Dąbrowski et al. 2017).

Two of the three new species, Barbus barbus and Salvelinus fontinalis, are freshwater fishes. The natural habitat of $B$. barbus are the upper and middle sections of fast flowing streams. This fish occurs in some Pomeranian rivers and lakes that are linked to the Baltic Sea. There is no evidence that barbel reproduces in the Baltic Sea. It only occurs intermittently in estuaries and brackish waters, e.g., in the Curonian Lagoon (Ådjers et al. 2006) or in the Gulf of Gdańsk (Skóra 1996). According to Thiel et al. (2013), adult B. barbus are encountered occasionally in the Baltic Sea coastal zone, but they do not occur in the coastal zones of the North Sea. Barbus barbus is considered a typical stenohaline freshwater species (Calin Sandu and Oprea 2013). This can be explained by a strong, permanent input of riverine waters to the coastal waters of Pomeranian Bay (Beszczyńska-Möller 1999).

Salvelinus fontinalis is an indigenous species of the north-eastern United States and Canada. It has also been released (intentionally or not) into different bodies of water (including brackish water) worldwide, where it is usually regarded as an invasive species. Some individuals commonly referred to as salters, move to the sea in the spring as stream temperatures rise, and they inhabit areas close to river mouths (Beitinger and Bennett 2000). In Europe, only non-anadromous populations are recorded (Kottelat and Freyhoff 2007), however, the non-migratory forms, when introduced directly into seawater, well adapt to salinity changes (Besner and Pelletier 1991). It is classified as a non-native species that was intentionally introduced for fishing and angling in the late nineteenth century in Baltic Sea drainage basin countries (Leppäkoski and Olenin 2000). Since then, escapees from hatcheries and aquaculture facilities located along the coast of the Baltic have been reported (Welcomme 1992).

Scophthalmus rhombus is a marine species, distributed from Norway to the Black Sea. According to Nielsen (1986) and Anonymous (2014), in the Baltic Sea, S. rhombus is distributed primarily in the western part, however, Heessen et al. (2015) noted its regular occurrence off Cape Arkona and around Bornholm. The eastern limit of its range has yet to be clearly defined. Skóra (1996) reported its presence in the Gulf of Gdańsk, but he categorized it as an extremely rare species. Grygiel (2009) described a 
Table 3

A checklist of fishes and lampreys recorded in Pomeranian Bay

\begin{tabular}{|c|c|c|}
\hline Family & Species & Reference \\
\hline \multirow[t]{3}{*}{ Petromyzontidae } & Lampetra fluviatilis (Linnaeus, 1758) & Dudko et al. 2015 \\
\hline & & Więcaszek et al. 2015 \\
\hline & Petromyzon marinus Linnaeus, 1758 & Więcaszek et al. 2015 \\
\hline Etmopteridae & Etmopterus spinax (Linnaeus, 1758) & Więcaszek et al. 2018 \\
\hline Acipenseridae & Acipenser gueldenstaedtii Brandt et Ratzeburg, 1833 & Keszka and Heese 2003 \\
\hline Anguillidae & Anguilla anguilla (Linnaeus, 1758) & Dudko et al. 2015 \\
\hline Engraulidae & Engraulis encrasicolus (Linnaeus, 1758) & Dudko et al. 2015 \\
\hline \multirow[t]{3}{*}{ Clupeidae } & Alosa fallax (Lacepède, 1803) & Krzykawski et at. 2001 \\
\hline & Clupea harengus Linnaeus, 1758 & Dudko et al. 2015 \\
\hline & Sprattus sprattus (Linnaeus, 1758) & Dudko et al. 2015 \\
\hline \multirow[t]{9}{*}{ Cyprinidae } & Abramis brama (Linnaeus, 1758) & Dudko et al. 2015 \\
\hline & Alburnus alburnus (Linnaeus, 1758) & Dudko et al. 2015 \\
\hline & Ballerus ballerus (Linnaeus, 1758) & Dudko et al. 2015 \\
\hline & Barbus barbus (Linnaeus, 1758) & This study \\
\hline & Blicca bjoerkna (Linnaeus, 1758) & Dudko et al. 2015 \\
\hline & Rutilus rutilus (Linnaeus, 1758) & Dudko et al. 2015 \\
\hline & Scardinius erythrophthalmus (Linnaeus, 1758) & Dudko et al. 2015 \\
\hline & Vimba vimba (Linnaeus, 1758) & Dudko et al. 2015 \\
\hline & Osmerus eperlanus (Linnaeus, 1758) & Dudko et al. 2015 \\
\hline \multirow[t]{3}{*}{ Salmonidae } & Coregonus maraena (Bloch, 1779) & Dudko et al. 2015 \\
\hline & Salmo trutta Linnaeus, 1758 & Dudko et al. 2015 \\
\hline & Salvelinus fontinalis (Mitchill, 1814) & This study \\
\hline Esocidae & Esox lucius Linnaeus, 1758 & Dudko et al. 2015 \\
\hline \multirow[t]{3}{*}{ Gadidae } & Gadus morhua Linnaeus, 1758 & Dudko et al. 2015 \\
\hline & Merlangius merlangus (Linnaeus, 1758) & Dudko et al. 2015 \\
\hline & Pollachius virens (Linnaeus, 1758) & Krzykawski et at. 2001 \\
\hline \multirow[t]{2}{*}{ Lotidae } & Enchelyopus cimbrius (Linnaeus, 1766) & Więcaszek et al. 2015 \\
\hline & Lota lota (Linnaeus, 1758) & Dudko et al. 2015 \\
\hline \multirow[t]{3}{*}{ Mugilidae } & Chelon labrosus (Risso, 1827) & Czerniejewski et al. 2008 \\
\hline & & Więcaszek et al. 2011 \\
\hline & Chelon ramada $(=$ Liza ramada $)($ Risso, 1827$)$ & Panicz and Keszka 2016 \\
\hline Belonidae & Belone belone (Linnaeus, 1760) & Dudko et al. 2015 \\
\hline \multirow[t]{2}{*}{ Gasterosteidae } & Gastereosteus aculeatus Linnaeus, 1758 & Dudko et al. 2015 \\
\hline & Spinachia spinachia (Linnaeus, 1758) & Więcaszek et al. 2015 \\
\hline \multirow[t]{2}{*}{ Syngnathidae } & Nerophis ophidion (Linnaeus, 1758) & Więcaszek et al. 2015 \\
\hline & Syngnathus typhle Linnaeus, 1758 & Więcaszek et al. 2015 \\
\hline \multirow[t]{2}{*}{ Triglidae } & Chelidonichthys lucerna (Linnaeus, 1758) & Krzykawski et at. 2001 \\
\hline & & Więcaszek et al. 2011 \\
\hline Cottidae & Myoxocephalus scorpius (Linnaeus, 1758) & Dudko et al. 2015 \\
\hline Agonidae & Agonus cataphractus (Linnaeus, 1758) & Więcaszek et al. 2015 \\
\hline \multirow[t]{2}{*}{ Cyclopteridae } & Cyclopterus lumpus Linnaeus, 1758 & Dudko et al. 2015 \\
\hline & & Więcaszek et al. 2015 \\
\hline Moronidae & Dicentrarchus labrax (Linnaeus, 1758) & Krzykawski et at. 2001 \\
\hline \multirow[t]{3}{*}{ Percidae } & Gymnocephalus cernua (Linnaeus, 1758) & Dudko et al. 2015 \\
\hline & Perca fluviatilis Linnaeus, 1758 & Dudko et al. 2015 \\
\hline & Sander lucioperca (Linnaeus, 1758) & Dudko et al. 2015 \\
\hline Carangidae & Trachurus trachurus (Linnaeus, 1758) & Więcaszek et al. 2011 \\
\hline Mullidae & Mullus surmuletus Linnaeus, 1758 & Więcaszek et al.2011 \\
\hline Labridae & Labrus bergylta Ascanius, 1767 & Keszka and Raczyński 2002 \\
\hline Zoarcidae & Zoarces viviparus (Linnaeus, 1758) & Dudko et al. 2015 \\
\hline Pholidae & Pholis gunnellus (Linnaeus, 1758) & Więcaszek et al. 2015 \\
\hline \multirow[t]{2}{*}{ Ammodytidae } & Ammodytes tobianus Linnaeus, 1758 & Dudko et al. 2015 \\
\hline & Hyperoplus lanceolatus (Le Sauvage, 1824) & Dudko et al. 2015 \\
\hline
\end{tabular}

Table continues on next page. 
Table 1 cont.

\begin{tabular}{lll}
\hline \multicolumn{1}{c}{ Family } & \multicolumn{1}{c}{ Species } & \multicolumn{1}{c}{ Reference } \\
\hline Trachinidae & Trachinus draco Linnaeus, 1758 & Krzykawski et at. 2001 \\
Gobiidae & Neogobius melanostomus (Pallas, 1814) & Dudko et al. 2015 \\
& Pomatoschistus minutus (Pallas, 1770) & Dudko et al. 2015 \\
Scombridae & Scomber scombrus Linnaeus, 1758 & Dudko et al. 2015 \\
Xiphiidae & Xiphias gladius Linnaeus, 1758 & Krzykawski et at. 2001 \\
Scophthalmidae & Scophthalmus maximus (Linnaeus, 1758) & Dudko et al. 2015 \\
& Scophthalmus rhombus (Linnaeus, 1758) & This study \\
Pleuronectidae & Platichthys flesus (Linnaeus, 1758) & Dudko et al. 2015 \\
& Pleuronectes platess Linnaeus, 1758 & Dudko et al. 2015 \\
\hline
\end{tabular}

single specimen of $S$. rhombus from the mid-Polish coast, caught in 2008. Plikšs and Aleksejevs (1998) reported single occurrences of $S$. rhombus in Latvian waters in the 1960s. There have been only scarce published records on length-weight relations, age, and the reproductive biology of $S$. rhombus carried out in the Atlantic Ocean and the Adriatic Sea (Turan et al. 2016).

Scophthalmus rhombus is a commercially exploited species, but not in the Baltic Sea where it usually appears as bycatch, and its stocks are currently not regulated by the Total Allowable Catch (TAC) quotas. In 2012-2015 the landings in SD 24-32 were null while in 2016 they amounted to $1 \mathrm{t}$. Swedish and Danish landings for the period of 2012-2016 were null in SD 24-32, while German landings in SD 22 (Kiel Bight and Mecklenburg Bay) amounted to $2 \mathrm{t}$ (no data for SD 24) (Anonymous 2017). It is unclear whether more than one stock of $S$. rhombus exists in the Baltic Sea, or if the Baltic population of $S$. rhombus is a part of a larger stock complex (Anonymous 2013). According to Blanquer et al. (1992), the weak geographic structure of brill seems to result from rapid re-colonization following the last ice age.

The growth rates of $S$. rhombus are slower in the northern parts of its distribution, and maturation is attained at shorter lengths; however, no precise data are available in the literature. In this study, the male specimens were aged $4+$ and $5+(17$ and $21.5 \mathrm{~cm} \mathrm{TL})$, while in the Adriatic Sea males aged $4+$ and $5+$ attained from 38 to $40 \mathrm{~cm}$ TL (Arneri et al. 2001). ICES categorizes the brill stock as 'data limited' in the Baltic Sea, where the detailed information from ICES stakeholders is not available (Anonymous 2017).

Parasites were recorded in alimentary tracts of $B$. barbus and $S$. rhombus. Results of only a few studies on the parasites of wild B. barbus in Europe have been published. The following species were reported: monogeneans Dactylogyrus carpathicus, D. malleus (see Grabda-Kazubska and Pilecka-Rapacz 1987), Diplozoon paradoxum, Gyrodactylus sp. (see Malanowski 1951, Ergens 1976), the leech Cystobranchus respirans (see Bielecki et al. 2011), glochidia larvae of the bivalve Sinanodonta woodiana (see Douda et al. 2012), the intestinal fluke Aspidogaster limacoides (see Schludermann et al. 2005), intestinal cestodes Caryophyllaeus brachycollis, C. laticeps, Khawia baltica, acanthocephalans Acanthocephalus lucii, Pomphorhynchus laevis (see Djikanovic et al. 2010), Neoechinorhynchus rutili (see Moravec and Scholz 1994), Acanthocephalus anguillae (see Herlyn and Ehlers
2001), and the microsporean Pleistophora longifilis (see Bauer 1984). In the presently reported study, only one intramuscular parasite (Myxobolus musculi) was noted in the juvenile B. barbus specimen. Myxobolus musculi has been reported in barbel specimens from the Danube River (Molnár et al. 2012), but has not previously been recorded in this fish species in Poland, where Myxobolus pfeifferi, M. cordis, and Eimeria carpelli are known from cultured fish (Malanowski 1951). Rhabdochona hellichi presently found in the adult $B$. barbus specimen is a nematode that was reported from Polish waters in two host species, Barbus barbus and Barbus peloponnesius Valenciennes, 1842. Described by Janiszewska (1955) as Rhabdochonoides barbi, it was detected in rivers of southern Poland and since then it has probably not been observed. This is a stenoxenic nematode that requires an obligatory intermediate host such as the caddisfly larvae of the genus Hydropsyche (see Okulewicz et al. 2008) that inhabits only rivers and streams. Specimens of the acanthocephalan $P$. laevis penetrated the intestinal wall of the adult barbel. This parasite has not been recorded previously in this fish species in Poland, however, it is a common parasite of flounder in the brackish waters of the Baltic Sea (Chibani and Rokicki 2004).

There have been only few studies on parasitic fauna of Scophthalmus rhombus. The parasites recovered from this fish include a myxozoan intestinal parasite Enteromyxum scophthalmi (see Losada et al. 2014), tapeworms Bothriocephalus scorpii (see Renaud et al. 1984), and $B$. andresi, the trypanorhynch mesenteric cestode Nybelinia lingualis, the digenean Derogenes varicus, the acantocephalan Acanthocephaloides propinquus (see Eiras 2016), and two species of copepods, Lepeophtheirus hippoglossi (see Hayward and Ryland 2003) and L. europaensis (see Dawson et al. 2000). However, data from the Baltic Sea are lacking. The ciliate Trichodina jadranica noted in this study has not yet been recorded nor in this host neither in other fishes from the Pomeranian Bay area. This parasite is typical for Platichthys flesus recorded in the Kiel Bight (Dobberstein and Palm 2000), in the Gulf of Riga (Kirjušina and Vismanis 2007), and also in Danish eel farms on Anguilla anguilla (see Madsen et al. 2000). The diameter of the adhesive discs differs slightly among specimens from P. flesus and A. anguilla, and they also differ among individuals, but the differences are recognized as intraspecific variations. In Pomeranian Bay another species of Trichodina was found, namely 
T. borealis in P. flesus (see Korlatowicz and Piasecki 2001), similarly like in the Gulf of Gdańsk (Chibani and Rokicki 2004). No ectoparasites were noted in this study, but they could have died because of their sensitivity to environmental changes from fresh to marine water.

The occurrence of Barbus barbus in Pomeranian Bay might have resulted from restocking activities and may represent the Oder River population. In recent years the density and the biomass of many rheophilous cyprinids have decreased considerably in many component river subsystems of the Oder River basin (Witkowski et al. 2007). In order to support the barbel population for over the past 15 years, a stocking program has been carried out by the Polish Angling Association in the West Pomeranian area*. In turn, the specimen of Salvelinus fontinalis, collected in this study, might have escaped from an aquaculture facility in Pomerania (Inter-boundary region of Poland and Germany). This could have happened, for example, when ponds were damaged during a severe thunderstorm, such as that reported in August 2017, when dozens of brook trout and sturgeon escaped into the Baltic Sea through the Pomeranian Grabowa River. Similarly, Keszka and Heese (2003) described two specimens of Acipenser gueldenstaedtii Brandt et Ratzeburg, 1833 in Pomeranian Bay that were likely escapees from fish farming facilities.

The occurrence of Scophthalmus rhombus specimens in Pomeranian Bay might be a result of its active migration from the Arkona or Bornholm areas or a passive translocation with inflows of higher-salinity waters from the western Baltic. A weak Major Baltic Inflow from the North Sea occurred in March 2014. Previously, two smaller inflow events in November 2013 and February 2014 affected the Bornholm Basin (Naumann et al. 2018). The presently reported occurrence of the fish specimens recorded for the first time in Pomeranian Bay can be related to stocking (B. barbel), aquaculture activities (S. fontinalis), the migratory behaviour of species, or inflows of highersalinity waters from the western Baltic (S. rhombus).

\section{REFERENCES}

Abbas B., Jaszkowiak K., Nawrocki A., Junge M., Rohde S., Kulaszka W., Demidowicz M., Siwka A., Mazur-Chrzanowska B., Landsberg-Uczciwek M., Zloczowska I., Wierzchowska E., Sroka E. 2015. Raport o jakości polsko-niemieckich wód granicznych 2014. Bericht über die Beschaffenheit der deutsch-polnischen Grenzgewässer 2014. Grupa robocza W2 „Ochrona wód” Polsko-Niemieckiej Komisji Wód Granicznych. Grudzień 2015. Arbeitsgruppe W2 "Gewässerschutz" der DeutschPolnischen Grenzgewässerkommission. Dezember 2015. Wojewódzki Inspektorat Ochrony Środowiska w Zielonej Górze, Zielona Góra, Poland. [In Polish.]

Ådjers K., Appelberg M., Eschbaum R., Lappalainen A., Minde A., Repečka R., Thoresson G. 2006. Trends in coastal fish stocks of the Baltic Sea. Boreal Environment Research 11 (1): 13-25.
Altschul S.F., Gish W., Miller W., Myers E.W., Lipman D.J. 1990. Basic local alignment search tool. Journal of Molecular Biology 215 (3): 403-410. DOI: 10.1016/ S0022-2836(05)80360-2

Anonymous 2013. Report of the ICES Advisory Committee 2013. Book 8. ICES, Copenhagen, Denmark.

Anonymous 2014. ECOREGION Baltic Sea, STOCK Brill in the Baltic, SCIENTIFIC NAME Scophthalmus rhombus. Digest of the ICES May 2014 Advice. ICES, Copenhagen, Denmark.

Anonymous 2017. Brill (Scophthalmus rhombus) in subdivisions 22-32 (Baltic Sea). ICES Advice on fishing opportunities, catch, and effort; Baltic Sea Ecoregion; bll.27.22-32. ICES, Copenhagen, Denmark. DOI: 10.17895/ices.pub.3057

Arneri E., Colella S., Giannetti G. 2001. Age determination and growth of turbot and brill in the Adriatic Sea: Reversal of the seasonal pattern of otolith zone formation. Journal of Applied Ichthyology 17 (6): 256-261. DOI: 10.1046/j.1439-0426.2001.00293.x

Bauer O.N. 1984. Opredelitel' parazitov presnovodnyh ryb fauny SSSR. Tom 1. Parazitičeskie prostejšie. [Key to the parasites of freshwater fishes of the USSR. Vol. 1. Parasitic protozoans.] Akademiâ Nauk SSSR, Zoologičeskij Institut, Leningrad, USSR.

Beitinger T.L., Bennett W.A. 2000. Quantification of the role of acclimation temperature in temperature tolerance of fishes. Environmental Biology of Fishes 58 (3): 277-288. DOI: 10.1023/A:1007618927527

Besner M., Pelletier D. 1991. Adaptation of the brook trout, Salvelinus fontinalis, to direct transfer to sea water in spring and summer. Aquaculture 97 (2-3): 217-230. DOI: 10.1016/0044-8486(91)90266-A

Beszczyńska-Möller A. 1999. Transport of the Odra River waters and circulation patterns in the Pomeranian Bay. Oceanologia 41 (3): 279-309.

Bielecki A., Cichocka J.M., Terlecki J., Witkowski A. 2011. The invasion of the leech Piscicola respirans (Hirudinea: Piscicolidae) on the fins of European grayling Thymalus thymalus. Biologia 66 (2): 294 298. DOI: $10.2478 / \mathrm{s} 11756-011-0019-0$

Blanquer A., Alayse J.P., Berrada-Rkhami O., Berrebi P. 1992. Allozyme variation in turbot (Psetta maxima) and brill (Scophthalmus rhombus) (Osteichthyes, Pleuronectiformes, Scophthalmidae) throughout their range in Europe. Journal of Fish Biology 41 (5): 725736. DOI: $10.1111 / \mathrm{j} .1095-8649.1992 . t b 02702 . x$

Calin Sandu P.G., Oprea L. 2013. Estimating fish communities structure and diversity from predeltaic Danube area. Animal Science and Biotechnologies 46 (2): 227-233.

Chibani M., Rokicki J. 2004. Seasonal occurrence of parasites of flounder Platichthys flesus (L.) from the Gulf of Gdańsk. Oceanological and Hydrobiological Studies 33 (3): 17-30.

Czerniejewski P., Keszka S., Rybczyk A. 2008. Chelon labrosus (Risso, 1827) - the first record from Lake Dąbie (Poland). Oceanologia 50 (2): 281-284. 
Dawson L.H.J., Renaud F., Guégan J.F., de Meeûs T. 2000. Experimental evidence of asymmetrical competition between two species of parasitic copepods. Proceedings of the Royal Society of London. Series B. Biological Sciences 267 (1456): 1973-1978. DOI: 10.1098/rspb.2000.1238

Dąbrowski J., Więcaszek B., Górecka K. 2017. Alien and invasive animal species in the food of predatory fish from the Pomeranian Bay. Pp. 47-48. In: Konferencja Międzynarodowa: Nauka w służbie przyrody - Genetyka konserwatorska i przeciwdziałanie inwazjom biologicznym. [International Conference: Science in service to nature-Conservation genetics and prevention of biological invasions.] 25-26 September 2017, Szczecin, Poland. [In English.]

Djikanovic V., Gacic Z., Cakic P. 2010. Endohelminth fauna of barbel Barbus barbus (L. 1758) in the Serbian section of the Danube River, with dominance of acanthocephalan Pomphorhynchus laevis. Bulletin of the European Association of Fish Pathologists 30 (6): 229-236.

Dobberstein R.C., Palm H.W. 2000. Trichodinid ciliates (Peritrichia: Trichodinidae) from the Bay of Kiel, with description of Trichodina claviformis sp. n. Folia Parasitologica 47 (2): 81-90. DOI: 10.14411/fp.2000.018

Douda K., Vrtílek M., Slavík O., Reichard M. 2012. The role of host specificity in explaining the invasion success of the freshwater mussel Anodonta woodiana in Europe. Biological Invasions 14 (1): 127-137. DOI: 10.1007/s10530-011-9989-7

Dudko S., Król S., Wojnar K., Wawrzyniak W. 2015. CharakterystykarybackaichtiofaunyZatokiPomorskiej (w oparciu o wyniki monitoring połowowego wykonanago w latach 2011-2014). [Fisheries characteristics of ichthyofauna of Pomeranian Bay (Based on the results of fishing monitoring carried out within 2011-2014)]. Wydawnictwo Josephs's Sons, Szczecin, Poland. [In Polish.] http://fishbayproject.pl/ files/fishbay_publikacja.pdf

Eiras J.C. 2016. Parasites of marine, freshwater and farmed fishes of Portugal: A review. Revista Brasileria de Parasitologia Veterinaria 25 (3): 259-278. DOI: 10.1590/S1984-29612016057

Ergens R. 1976. Gyrodactylus barbi sp.n. (Monogenoidea) from the fins of barbels. Věstnik českoslvenské společnosti zoologické 40 (3): 161-162.

Grabda-Kazubska B., Pilecka-Rapacz M. 1987. Parasites of Leuciscus idus (L.), Aspius aspius (L.) and Barbus barbus (L.) from the river Vistula near Warszawa. Acta Parasitologica Polonica 31 (25): 219-230.

Grygiel W. 2009. Niektóre obce i rzadkie gatunki ryb w polskich połowach na Bałtyku [Some alien and rare fish species in Polish catches in the Baltic Sea.] Wiadomości Rybackie 3-4 (168): 11-14. [In Polish.]

Hall T.A. 1999. BioEdit: a user-friendly biological sequence alignment editor and analysis program for Windows 95/98/NT. Nucleic Acids Symposium Series 41: 95-98.

Hayward P.J., Ryland J.S. (eds.) 2003. Handbook of the marine fauna of north-west Europe. 2nd edn.) Oxford University Press, Oxford, UK.
Heessen H.J.L., Daan N., Ellis J.R. (eds.) 2015. Fish atlas of the Celtic Sea, North Sea, and Baltic Sea. Based on international research-vessel surveys. KNNV Publishing, Wageningen Academic Publishers.

Herlyn H., Ehlers U. 2001. Organisation of the praesoma in Acanthocephalus anguillae (Acanthocephala, Palaeacanthocephala) with special reference to the muscular system. Zoomorphology 121 (1): 13-18. DOI: $10.1007 / \mathrm{s} 004350100039$

Janiszewska J. 1955. Rhabdochonoides barbi g. n., sp. n., subfamily Rhabdochonoidinae subfam. n. (Fam. Rhabdochonidae Skrjabin) an intestinal parasite in cyprinid fish. Acta Parasitologica Polonica 3 (9): 233-244.

Keszka S., Heese T. 2003. Occurrence of exotic Russian sturgeons, Acipenser gueldenstaedtii Brandt et Ratzeburg, 1833 (Actinopterygii: Acipenseridae) in the Baltic Sea. Acta Ichthyologica et Piscatoria 33 (2): 173-178. DOI: 10.3750/AIP2003.33.2.07

Keszka S., Raczyński M. 2002. Wargacz kniazik Labrus bergylta Ascanius, 1767 u wybrzeży polskich. [Ballan wrasse Labrus bergylta Ascanius, 1767 off Polish coasts.] Komunikaty Rybackie 2002 (5): 22-23. [In Polish.]

Kirjušina M., Vismanis K. 2007. Checklist of the parasites of fishes of Latvia. FAO Fisheries Technical Paper: 369/3. FAO, Rome.

Korlatowicz A., Piasecki W. 2001. Parasite fauna of flounder, Platlchthys flesus (L.) from the Pomeranian Bay, southwestern Baltic Sea. Wiadomości Parazytologiczne 47 (Suppl. 2): 24.

Kottelat M., Freyhof J. 2007. Handbook of European freshwater fishes. Kottelat and Freyhof, Cornol, Switzerland, Berlin, Germany.

Krzykawski S., Więcaszek B., Keszka S. 2001. The taxonomic revue of representatives of the extremely rare species in Polish waters collected within 19931999. Folia Universitas Agriculturae Stetinensis 218 Piscaria 28: 53-62.

Leppäkoski E., Olenin S. 2000. Non-native species and rates of spread: Lessons from the brackish Baltic Sea. Biological Invasions 2 (2): 151-163. DOI: 10.1023/A:1010052809567

Losada A.P., Bermúdez R., Faílde L.D., Di Giancamillo A., Domeneghini C., Quiroga M.I. 2014. Effects of Enteromyxum scophthalmi experimental infection on the neuroendocrine system of turbot, Scophthalmus maximus (L.). Fish and Shellfish Immunology 40 (2): 577-583. DOI: 10.1016/j.fsi.2014.08.011

Madsen H.C.K., Buchmann K., Mellergaard S. 2000. Trichodina sp. (Ciliophora: Peritrichida) in eel Anguilla anguilla in recirculation systems in Denmark: Hostparasite relations. Diseases of Aquatic Organisms 42 (2): 149-152. DOI: 10.3354/dao042149

Malanowski Z. 1951. Fauna pasożytnicza brzany (Barbus barbus L.) z środkowego biegu Wisły. [Parasite fauna of Barbus barbus from the middle section of the Vistula River.] Roczniki Nauk Rolniczych 58: 373 383. [In Polish.]

Molnár K., Eszterbauer E., Marton S., Székely C., Eiras J.C. 2012. Comparison of the Myxobolus fauna 
of common barbel from Hungary and Iberian barbel from Portugal. Diseases of Aquatic Organisms 100 (3): 231-248. DOI: 10.3354/dao02469

Moravec F., Scholz T. 1994. Seasonal occurrence and maturation of Neoechinorhynchus rutili (Acanthocephala) in barbel, Barbus barbus (Pisces), of the Jihlava River, Czech Republic. Parasite 1 (3): 271-278. DOI: 10.1051/parasite/1994013271

Naumann M., Mohrholz V., Waniek J. 2018. Water exchange between the Baltic Sea and the North Sea, and conditions in the deep basins. HELCOM Baltic Sea Environmental Fact Sheet 2017.

Nielsen J.G. 1986. Scophthalmidae. Pp. 1291-1292. In: Whitehead P.J.P., Bauchot M.-L., Hureau J.-C., Nielsen J., Tortonese E. (eds.) Fishes of the Northeastern Atlantic and the Mediterranean. Vol. 3. UNESCO, Paris.

Ojaveer H., Jaanus A., MacKenzie B.R., Martin G., Olenin S., Radziejewska T., Telesh I., Zettler M.L., Zaiko A. 2010. Status of biodiversity in the Baltic Sea. PLoS ONE 5 (9): e12467. DOI: 10.1371/journal. pone. 0012467

Okulewicz A., Perec-Matysiak A., Hildebrand J., Zaleśny G. 2008. Specyficzność żywicielska krajowych nicieni. [Host specificity of domestic nematodes.] Wiadomości Parazytologiczne 54 (1): 11-16. [In Polish.]

Panicz R., Keszka S. 2016. First occurrence of thinlip grey mullet, Liza ramada (Risso, 1827) in the Odra River estuary (NW Poland): genetic identification. Oceanologia 58 (3): 196-200. DOI: 10.1016/j. oceano.2016.02.001

Plikšs M., Aleksejevs E. 1998. Zivis [Fishes.] Latvijas daba, sugu enciklopēdija. [Nature of Latvia, Species Encyclopaedia.] Gandrs, Riga, Latvia. [In Latvian.]

Psuty-Lipska I., Garbacik-Wesolowska A. 1998. Species composition and fish distribution in the Pomeranian Bay and the Szczecin Lagoon. Bulletin of the Sea Fisheries Institute 1998 (3): 2-20.

Renaud F., Gabrion C., Romestand B. 1984. Le complexe Bothriocephalus scorpii (Mueller, 1776). Différenciation des espèces parasites du Turbot (Psetta maxima) et de la Barbue (Scophthalmus rhombus). Étude des fractions protéiques et des complexes antigéniques. Annales de Parasitologie Humaine et Comparee 59 (2): 143-149.

Schludermann C., Laimgruber S., Konecny R., Schabuss M. 2005. Aspidogaster limacoides Diesing, 1835 (Trematoda, Aspidogastridae): A new parasite of Barbus barbus (L.) (Pisces, Cyprinidae) in Austria. Annalen des Naturhistorischen Museums in Wien. Serie B für Botanik und Zoologie 106: 141-144.

Sevilla R.G., Diez A., Norén M., Mouchel O., Jérôme M., Verrez-Bagnis V., van Pelt H., Favre-Krey L., Krey G., the Fishtrace Consortium, Bautista J.M. 2007. Primers and polymerase chain reaction conditions for DNA barcoding teleost fish based on the mitochondrial cytochrome $b$ and nuclear rhodopsin genes. Molecular Ecology Resources 7 (5): 730-734. DOI: $10.1111 / \mathrm{j} .1471-8286.2007 .01863 . \mathrm{x}$

Skóra K. 1996. New and rare fish species from the Gulf of Gdańsk. Zoologica Poloniae 41 (Suppl.): 113-130. [In Polish.]

Thiel R., Winkler H., Böttcher U., Dänhardt A., Fricke R., George M., Kloppmann M., Schaarschmidt T., Ubl C., Vorberg R. 2013. Rote Liste und Gesamtartenliste der etablierten Fische und Neunaugen (Elasmobranchii, Actinopterygii und Petromyzontida) der marinen Gewässer Deutschlands. In: Becker N., Haupt H., Hofbauer N., Ludwig G., Nehring S. (eds.) Rote Liste gefährdeter Tiere, Pflanzen und Pilze Deutschlands, Band 2: Meeresorganismen. Münster (Landwirtschaftsverlag). Naturschultz und Biologische Vielfalt 70 (2): 11-76.

Turan C., Yağlioğlu D., Ergüden D., Gürlek M., Uyan A., Karan S., Doğdu S. 2016. Threatened brill species in marine waters of Turkey: Scopthalmus [sic] rhombus (Linnaeus, 1758) (Scopthalmidae [sic]). Natural and Engineering Sciences 1 (1): 1-6.

Welcomme R.L. 1992. A history of international introductions of inland aquatic species. ICES Marine Science Symposia 194: 3-14.

Więcaszek B., Sobecka E., Dudko S., Keszka S. 2011. New and 'visiting' fish species collected off the western coast of Poland (Baltic Sea) in 2007-2008 with a description of their parasite fauna. Oceanologia 53 (1): 163-179. DOI: $10.5697 /$ oc.53-1.163

Więcaszek B., Sobecka E., Keszka S., Stepanowska K., Dudko S., Biernaczyk M., Wrzecionkowski K. 2015. Studies on endangered and rare non-commercial fish species recorded in the Pomeranian Bay (southern Baltic Sea) in 2010-2013. Helgoland Marine Research 69 (4): 411-416. DOI: 10.1007/s10152-015-0442-7

Więcaszek B., Sobecka E., Panicz R., Keszka R., Górecka K., Linowska A. 2018. First record of the deep-water shark Etmopterus spinax (Chondrichthyes: Etmopteridae) from the southern Baltic Sea (Pomeranian Bay). Oceanologia 60 (3): 426-430. DOI: 10.1016/j.oceano.2018.02.001

Winkler H.M. 2006. Die Fischfauna der südlichen Ostsee. Meeresangler-Magazin 16: 17-18.

Winkler H.M., Skóra K., Repecka R., Ploks M., Neelov A., Urho L., Gushin A., Jespersen H. 2000. Checklist and status of fish species in the Baltic Sea. ICES CM 2000/Mini Symposium 11: 1-15.

Witkowski A., Penczak T., Kotusz J., Przybylski M., Kruk A., Błachuta J. 2007. Reophilous cyprinid fishes of the Odra River basin. Roczniki Naukowe Polskiego Związku Wędkarskiego 20: 5-33.

Received: 26 January 2018

Accepted: 4 October 2018

Published electronically: 15 March 2019 